\title{
The Application of Al-Ijarah Muntahiya Bi al tamlik (Financial Lease With Purchase Option) As a Financing Solution in the Sharia Non-Bank Finance Industry
}

\author{
Bustami $^{1^{*}}$ \\ ${ }^{1}$ Tanjungpura University, Pontianak, Indonesia
}

\begin{abstract}
To avoid buying and selling through installment (credit) that does not fall in buying and selling that contains the element of riba (that is not allowed by sharia), buying and selling through credit or bai' al taqsit\} is able to be implemented by using a pact of selling and leasing through the financing principle of Al-Ijarah Muntahiya Bi al Tamlik (Financial Lease With Purchase Option). The application of the AlIjarah Muntahiya Bi al Tamlik is more advantageous than the al-Murabahah pact and the interest system. Other than that it reflects the presence of the principles of justice and togetherness between the capital owner party (shahib al mal) with those that need financing.
\end{abstract}

Keywords: Al-Ijarah Muntahiya Bi al tamlik, Bai' al taqsîth, Justice, Togetherness

\section{INTRODUCTION}

With the development of civilization in a nation, the people's demand of goods and services in the relevant nation in the frame of fulfilling needs and desires, experience continuous development beginning from the type, quality up to trendy fashion. In the beginning, the people's demand of goods and services are still limited to fulfilling primary needs (food, clothing, and a home). The development of demands of the goods and services will appear clearer when an income increase occurs and the presence of expectations (lures), an increase in income will occur in the future. Other than that, an increase in the demand of goods and services that are not primary needs is also accommodated by the condition of the people's environment. In fulfilling desires for obtaining goods and services that are not primary needs that are more diverse, those that do not have cash, implement purchasing by paying in installments (which is known as buying and selling with credit)

The word kredit in the Indonesian language is taken from the latin language "credo" which means I believe, in other words I believe in the ability of someone to pay. This trust is based on an agreement. So there are times when credit is only used as: "an agreement to pay money or as permission for using another person's capital.

It is said that in the modern economy, the problem of credit does not only occur in the transactions of borrowing money in banks, but has already spread to the transaction of buying and selling goods (which is known as buying and selling with credit), starting from simple goods up to luxury goods (houses, clothes,

* Corresponding author. Email address: bustami_ptk@yahoo.com 
washing machines, car cooking equipment, motorcycles and others) Credit buying and selling of this type is already common, done by those that do not have cash money nor those that have cash money (these are actually able to buy in cash, but because of certain reasons, they buy in installments.

In the conventional economic concept, buying and selling with installments is named credit buying and selling or leasing (financial lease). In practice, this credit buying and selling has widely developed, implemented institutionally (financing institutions) or individually (an individual does the selling from house to house). Institutionally, financial lease are usually transactions of credit buying and selling implemented for goods that have relatively expensive prices (such as houses, cars, motorcycles, television, refrigerators, washing machines and others). The amount of installments are determined based on accumulated interest rates. While the practice of individual credit buying and selling are usually credit buying and selling transactions implemented for simple goods and a relatively cheap price, such as kitchen equipment and clothes. For this last type of transaction, the amount of installments are determined based on the length of the grace period and the payment frequency, for example a good that is priced at Rp.100,000 in cash, if it uses installments for six months (six times payment), the price is Rp.200,000, and if it uses installments for one year (twelve times payment), the price is Rp.300,000.

In the Islamic economy perspective, both forms of credit buying and selling like this (based on interest or the price based on the payment time period) is able to be categorized as transactions that contains riba. Islamic scholars often use several hadith that are considered to be connected with this problem. One of them is the legacy hadith of Imam Tirmizi that reads (Ar-Rahim, 1410 H/1990 M:357):

حد ثنا هناد حد ثنا عبدة بن سليمان عن محمد بن عمرو عن أبى سلمة عن أبى هريرة قال : نهي

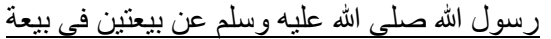

Meaning: Hannad tells us telling about Abdah bin Sulaiman to us from Muhammad bin Amr from Salamah from the eyes of Abi Hurairah;"'Rasulullah SAW forbids two sales or two transactions for one product".

In modern life most people are unable to be free from the practice of credit buying and selling, whether they are economically able or not, especially for fulfilling desires of secondary goods (not goods of primary needs, such as credit of permanent house ownership, cars, motorcycles

In the Islamic economy literature, credit buying and selling is known with the term bai' al-Taqsith. According to Zuhaily (2002:311), bai'al-Taqsit is the opposite word of cash buying and selling bai al-najaz, which is a model of buying and selling with the payment behind it, at once or using installments. According to Al-Mishry (1998/1418 H:11) bai' al taqsit\} is a contemporary example of the classic mu'amalah practice. Therefore it is able to be said that bai' al taqsit\} is buying by using installments in a timeframe that is determined/agreed together between the buyer and seller. From both types of buying and selling transactions (credit buying and selling or bai' al taqsit\}, there are elements of price adding between cash and non-cash (credit).

Because of that for helping consumers to be able to own something and for avoiding so that buying and selling through installments (credit) does not fall as buying and selling that contains the element of riba (which is not allowed by sharia), credit buying and selling or bai' al taqsit\}, is able to be implemented by using the pact of buying and leasing through the financing principle of Al-Ijarah Muntahiya Bi al Tamlik (Financial Lease With Purchase Option). 


\section{METHODOLOGY}

This writing is a representation of one of the chapters (chapter 5) of the writer's thesis (Bustami, 2015:142-153), which is titled "The Empowerment of Micro, Small, and Middle Class Businesses in West Kalimantan (An Islamic Economy Perspective)" that the writer has already maintained in the open senate session Doctoral Promotion Test in the field of Islamic Religion Science in the Concentration of Islamic Economy, Graduate School Syarif Hidatullah Jakarta, dated September 8, 2015.

\subsection{Testing Results}

This research uses an experiment approach. Therefore data that is presented in this writing are results of tests (experiments) of the writer from $2008-2013$. Before implementing tests, the writer with some colleagues established a koperasi, which is Koperasi Serba Usaha Syariah Ridha Madani, Legal Entity No. 52/XVII.10/2008 with members as many as 36 persons.

The tests are implemented by providing financing in the form of productive financing (business capital aid) and consumptive financing (for giving goods, such as computers, laptops, motorcycles and others). In the test the financing is given tob 40 customers that are given financing. From the amount there are 24 persons that are given financing that is said to be procurement of goods (consumptive) by using the leasing and buying pact through the financing principle of Al-Ijarah Muntahiya Bi al Tamlik (Financial Lease With Purchase Option). From the 24 persons, there are 3 persons (as many as $7.5 \%$ ) that fail to pay. This failure is caused by technical problems when billing (the debt party changed the address without knowing).

\subsection{Literature Research}

Then for enriching data or information that the writer obtained through the research activity of the experiment results, so that this writing is worth consuming by several circles, the writer also gathered information through several references (secondary data, literature, magazines, journals, and e-journals) that is written by academics and experts through national and international journals in several printed and electronic media (through browsing activity on the internet).

\section{RESULTS AND DISCUSSION}

This form of buying and selling is none other than only a form of nasi'ah buying and selling, which is buying and selling by handing over goods up front, while the payment is not in cash or behind, it is done at once or with installments with details that are already agreed (Al-Mishry, 1998/1418 H:11)

The terminology of Al-Ijarah Muntahiya Bi al Tamlik (IMTB) is a term that is commonly used in Indonesia, while in Malaysia the term Al-Ijarah Thumma Al$B a y^{\prime}(A I T A B)$ is used, which is a pact of leasing a certain good that is ended with a diversion of ownership to the lessor (Hakim, 2011:233-256; Djamil, 2012:150-164; Dusuki, tt; Jusoh, 2013:47-55)

In relation with the application of $I M B T$, the writer implemented experiments in consumptive financing (computers, televisions, cell phones, two wheeled motor vehicles) for \pm five years (2008-2013) by using a pact of buying and leasing through the financing principle of Al-Ijarah Muntahiya Bi al Tamlik (Financial Lease With Purchase Option). In Malaysia the implementation of Al-Ijarah Thumma Al-Bay' (AITAB) has a very large prospect (Abdullah \& Dusuki, tt:10-11) The $A I T A B$ prospect size is illustrated from four aspects, which are the strength of 
people support, the competitiveness of the AITAB implementation, legal protection, and corresponding with sharia demands.

Then the research of Jusoh (2013:47-55), shows that Al-Ijarah Thumma AlBay' (AITAB) in Malaysia provides a contribution of 31.2 percent in 2009 and 27.8 percent in 2010 from the whole financing of Islamic banking in Malaysia.

\subsection{Financing Count With Al-Ijarah Muntahiya Bi al Tamlik}

In the implementation of this pact, when the candidate customer proposes a number of funds to the fund provider (shahib al mal) for purchasing goods (almabi') that he/she wants, hence the fund provider (shahib al mal), the candidate customer is welcomed to choose goods in the seller's store that is corresponding with his/her desires (from the type and quality, or from the prices)

After the person determines the type of good that he/she wants in one of the chosen stores, the fund providing party with the candidate customer visits the store to pay for the good in corresponding with the desire of the candidate customer (corresponding with type, quality, or the price that is chosen). This action is implemented for ensuring that the candidate customer really uses the loaned fund for buying the good that is corresponding with the proposed loaned fund (and does not mark up the price).

Because the good that is agreed in the pact is the choice of the candidate customer, there is no reason from the candidate customer to cancel the pact or return the good to the fund provider because the type, quality, and price is not corresponding with his/her desire. Other than that, it is also for keeping transparence from the shahib al mal to the candidate customer. Schematically, the flow of $I M B T$ funding is able to be seen in the figure below.

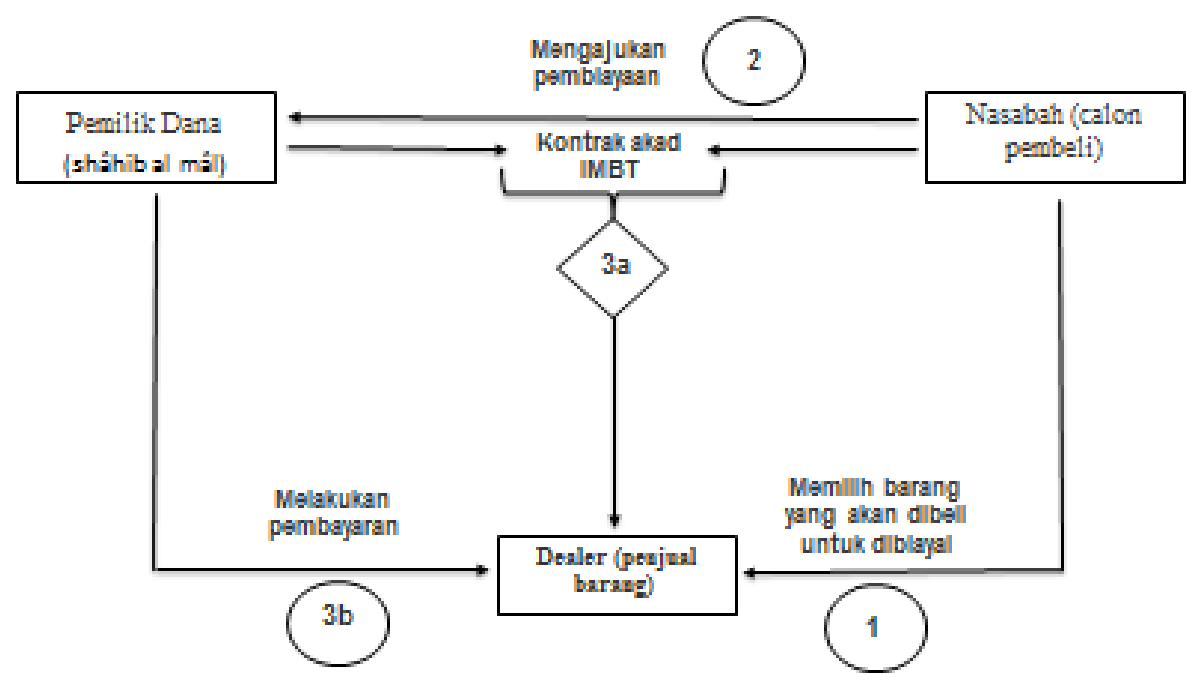

Figure 1 Operational Flow of IMBT Funding

As for the operationalization from the Al-Ijarah Muntahiya Bi al Tamlik (Financial Lease With Purchase Option) is able to be explained with the case study as the following:

A customer (Fulan for example) is meant to buy a Honda motorcycle (used motorcycle) in an agent of sales (dealer) for Rp.7, 300,000. Fulan only has cash as 
many as Rp. 1,500,000. Because Fulan really needs the motorcycle, he visits the financing institute (KSUS-RM for example) and proposes a loan for enclosing the fund deficit in paying the vehicle to the selling party (dealer), which is as many as Rp. 5,800,000. By the KSUS-RM party explained that the financing is implemented with two choices which is the Al-Murabahah pact (which is the pact of buying and selling goods with the primary buying price (price of the selling store) added with profit (price mark up) that the fund providing party wants) or Al-Ijarah Muntahiya Bi al Tamlik (Financial Lease With Purchase Option). Fulan asks for an explanation of the pacts that are meant, then Fulan chooses the pact of Al-Ijarah Muntahiya Bi al Tamlik (Financial Lease With Purchase Option).

Because the vehicle that will be funded is a used vehicle, the KSUS-RM party inspects the vehicle's condition first, to determine its economic age. What is meant by economic age in here is the length of use that the vehicle is able to be operated normally without the costs of changing primary components (internal engine components) except for changing tires and the spark plug. Which means the vehicle that is funded will effectively provide a clean benefit that is positive and is able to be operated until some or all of the primary components have to be changed.

After being observed the vehicle is estimated to have an economic age of 48 months (4 years), fulan agrees with the results of the research, then Fulan and KSUS-RM agrees to determine the lease of the vehicle per month, and a nominal lease value of the vehicle as many as Rp. $152,083.33$ per month is obtained. If Fulan asks KSUS-RM about payment of installments and ijarah with the same amount every month in corresponding with his financial condition, in the installment time period as long as 21 months, the counting illustration is as in the following table 1 .

Table 1 Illustration of Al-Ijarah Muntahiya Bi al Tamlik (Financial Lease

With Purchase Option) with the same installments per month.

\begin{tabular}{|c|c|c|c|c|c|c|c|}
\hline \multirow[t]{2}{*}{ Month } & \multirow{2}{*}{$\begin{array}{l}\text { Primary } \\
\text { Funding } \\
\text { (Rupiah) }\end{array}$} & \multirow{2}{*}{$\begin{array}{c}\text { Primary } \\
\text { Installment } \\
\text { (Rupiah) }\end{array}$} & \multirow{2}{*}{$\begin{array}{c}\text { Accumulated } \\
\text { Installment } \\
\text { Payment } \\
\text { (Rupiah) }\end{array}$} & \multicolumn{2}{|c|}{$\begin{array}{c}\text { Nisbah } \\
\text { Ownership*) }\end{array}$} & \multirow[t]{2}{*}{$\begin{array}{l}\text { Amount of } \\
\text { ujrah that } \\
\text { Fulan pays } \\
\text { (Rupiah) }\end{array}$} & \multirow[t]{2}{*}{$\begin{array}{c}\text { Payment } \\
\text { Amount per } \\
\text { month } \\
\text { (Rupiah) } \\
\end{array}$} \\
\hline & & & & $\begin{array}{c}\text { Fulan } \\
(\%)\end{array}$ & $\begin{array}{c}\text { KSUS- } \\
\text { RM }(\%)\end{array}$ & & \\
\hline ( 1 ) & $(2)$ & (3) & (4) & $(5)$ & (6) & $(7)$ & $(8)$ \\
\hline 1 & $5.800 .000,00$ & $224.166,67$ & $1.724 .166,67$ & 0,21 & 0,79 & $120.833,33$ & $345.000,00$ \\
\hline 2 & $5.575 .833,33$ & $228.836,81$ & $1.953 .003,47$ & 0,24 & 0,76 & $116.163,19$ & $345.000,00$ \\
\hline 3 & $5.346 .996,53$ & $233.604,24$ & $2.186 .607,71$ & 0,27 & 0,73 & $111.395,76$ & $345.000,00$ \\
\hline 4 & $5.113 .392,29$ & $238.470,99$ & $2.425 .078,71$ & 0,30 & 0,70 & $106.529,01$ & $345.000,00$ \\
\hline 5 & $4.874 .921,29$ & $243.439,14$ & $2.668 .517,84$ & 0,33 & 0,67 & $101.560,86$ & $345.000,00$ \\
\hline 6 & $4.631 .482,16$ & $248.510,79$ & $2.917 .028,63$ & 0,37 & 0,63 & $96.489,21$ & $345.000,00$ \\
\hline 7 & $4.382 .971,37$ & $253.688,10$ & $3.170 .716,73$ & 0,40 & 0,60 & $91.311,90$ & $345.000,00$ \\
\hline 8 & $4.129 .283,27$ & $258.973,27$ & $3.429 .690,00$ & 0,43 & 0,57 & $86.026,73$ & $345.000,00$ \\
\hline 9 & $3.870 .310,00$ & $264.368,54$ & $3.694 .058,54$ & 0,47 & 0,53 & $80.631,46$ & $345.000,00$ \\
\hline 10 & $3.605 .941,46$ & $269.876,22$ & $3.963 .934,76$ & 0,51 & 0,49 & $75.123,78$ & $345.000,00$ \\
\hline 11 & $3.336 .065,24$ & $275.498,64$ & $4.239 .433,40$ & 0,54 & 0,46 & $69.501,36$ & $345.000,00$ \\
\hline 12 & $3.060 .566,60$ & $281.238,20$ & $4.520 .671,59$ & 0,58 & 0,42 & $63.761,80$ & $345.000,00$ \\
\hline 13 & $2.779 .328,41$ & $287.097,32$ & $4.807 .768,92$ & 0,62 & 0,38 & $57.902,68$ & $345.000,00$ \\
\hline 14 & $2.492 .231,08$ & $293.078,52$ & $5.100 .847,44$ & 0,66 & 0,34 & $51.921,48$ & $345.000,00$ \\
\hline 15 & $2.199 .152,56$ & $299.184,32$ & $5.400 .031,76$ & 0,70 & 0,30 & $45.815,68$ & $345.000,00$ \\
\hline 16 & $1.899 .968,24$ & $305.417,33$ & $5.705 .449,09$ & 0,74 & 0,26 & $39.582,67$ & $345.000,00$ \\
\hline 17 & $1.594 .550,91$ & $311.780,19$ & $6.017 .229,28$ & 0,78 & 0,22 & $33.219,81$ & $345.000,00$ \\
\hline
\end{tabular}


AFEBI Islamic Finance and Economic Review (AIFER)

Vol.02 No.01, June 2017

\begin{tabular}{|c|c|c|c|c|c|c|c|}
\hline \multirow[t]{2}{*}{ Month } & \multirow[t]{2}{*}{$\begin{array}{l}\text { Primary } \\
\text { Funding } \\
\text { (Rupiah) }\end{array}$} & \multirow[t]{2}{*}{$\begin{array}{c}\text { Primary } \\
\text { Installment } \\
\text { (Rupiah) }\end{array}$} & \multirow{2}{*}{$\begin{array}{l}\text { Accumulated } \\
\text { Installment } \\
\text { Payment } \\
\text { (Rupiah) }\end{array}$} & \multicolumn{2}{|c|}{$\begin{array}{c}\text { Nisbah } \\
\text { Ownership*) }\end{array}$} & \multirow[t]{2}{*}{$\begin{array}{c}\text { Amount of } \\
\text { ujrah that } \\
\text { Fulan pays } \\
\text { (Rupiah) }\end{array}$} & \multirow[t]{2}{*}{$\begin{array}{c}\text { Payment } \\
\text { Amount per } \\
\text { month } \\
\text { (Rupiah) }\end{array}$} \\
\hline & & & & $\begin{array}{c}\text { Fulan } \\
(\%)\end{array}$ & $\begin{array}{c}\text { KSUS- } \\
\text { RM (\%) }\end{array}$ & & \\
\hline 18 & $1.282 .770,72$ & $318.275,61$ & $6.335 .504,89$ & 0,82 & 0,18 & $26.724,39$ & $345.000,00$ \\
\hline 19 & $964.495,11$ & $324.906,35$ & $6.660 .411,24$ & 0,87 & 0,13 & $20.093,65$ & $345.000,00$ \\
\hline 20 & $639.588,76$ & $331.675,23$ & $6.992 .086,47$ & 0,91 & 0,09 & $13.324,77$ & $345.000,00$ \\
\hline 21 & $307.913,53$ & $307.913,53$ & $7.300 .000,00$ & 0,96 & 0,04 & $6.414,87$ & $314.328,39$ \\
\hline \multicolumn{2}{|c|}{ Total payment } & $5.800 .000,00$ & & 1,00 & 0,00 & $1.414 .328,39$ & 7.214.328,39 \\
\hline
\end{tabular}

Source: Experiment Results.

*) Nisbah ownership in column (5) and (6), is meant for determining the amount of ujrah that Fulan pays every month, and is also used as a guide in determining the amount of each party's return rights if until a period Fulan is not able to continue the contract of the pact.

If Fulan asks KSUS-RM for the primary payment of installments to be paid with the same amount every month and submitted to KSUS-RM to determine the amount (primary installments added with ujrah) that he has to pay every month, the counting illustration is as in the following table 2 .

Table 2 Illustration of Al-Ijarah Muntahiya Bi al Tamlik (Financial

Lease With Purchase Option) with the same primary installments per month.

\begin{tabular}{|c|c|c|c|c|c|c|c|}
\hline \multirow[b]{2}{*}{ Month } & \multirow{2}{*}{$\begin{array}{l}\text { Primary } \\
\text { Funding } \\
\text { (Rupiah) }\end{array}$} & \multirow{2}{*}{$\begin{array}{c}\text { Primary } \\
\text { Installment } \\
\text { (Rupiah) }\end{array}$} & \multirow{2}{*}{$\begin{array}{c}\text { Accumulated } \\
\text { Installment } \\
\text { Payment } \\
\text { (Rupiah) }\end{array}$} & \multicolumn{2}{|c|}{$\begin{array}{c}\text { Nisbah } \\
\text { Ownership }\end{array}$} & \multirow{2}{*}{$\begin{array}{l}\text { Amount of } \\
\text { ujrah that } \\
\text { Fulan pays } \\
\text { (Rupiah) }\end{array}$} & \multirow{2}{*}{$\begin{array}{c}\text { Payment } \\
\text { Amount per } \\
\text { month } \\
\text { (Rupiah) }\end{array}$} \\
\hline & & & & $\begin{array}{c}\text { Fulan } \\
(\%)\end{array}$ & $\begin{array}{c}\text { KSUS- } \\
\text { RM } \\
(\%)\end{array}$ & & \\
\hline (1) & $(2)$ & (3) & $(4)$ & $(5)$ & (6) & $(7)$ & $(8)$ \\
\hline 1 & $5.800 .000,00$ & $276.190,48$ & $1.776 .190,48$ & 0,21 & 0,79 & $120.833,33$ & $397.023,81$ \\
\hline 2 & $5.523 .809,52$ & $276.190,48$ & $2.052 .380,95$ & 0,24 & 0,76 & $115.079,37$ & $391.269,84$ \\
\hline 3 & $5.247 .619,05$ & $276.190,48$ & $2.328 .571,43$ & 0,28 & 0,72 & $109.325,40$ & $385.515,87$ \\
\hline 4 & $4.971 .428,57$ & $276.190,48$ & $2.604 .761,90$ & 0,32 & 0,68 & $103.571,43$ & $379.761,90$ \\
\hline 5 & $4.695 .238,10$ & $276.190,48$ & $2.880 .952,38$ & 0,36 & 0,64 & $97.817,46$ & $374.007,94$ \\
\hline 6 & $4.419 .047,62$ & $276.190,48$ & $3.157 .142,86$ & 0,39 & 0,61 & $92.063,49$ & $368.253,97$ \\
\hline 7 & $4.142 .857,14$ & $276.190,48$ & $3.433 .333,33$ & 0,43 & 0,57 & $86.309,52$ & $362.500,00$ \\
\hline 8 & $3.866 .666,67$ & $276.190,48$ & $3.709 .523,81$ & 0,47 & 0,53 & $80.555,56$ & $356.746,03$ \\
\hline 9 & $3.590 .476,19$ & $276.190,48$ & $3.985 .714,29$ & 0,51 & 0,49 & $74.801,59$ & $350.992,06$ \\
\hline 10 & $3.314 .285,71$ & $276.190,48$ & $4.261 .904,76$ & 0,55 & 0,45 & $69.047,62$ & $345.238,10$ \\
\hline 11 & $3.038 .095,24$ & $276.190,48$ & $4.538 .095,24$ & 0,58 & 0,42 & $63.293,65$ & $339.484,13$ \\
\hline 12 & $2.761 .904,76$ & $276.190,48$ & $4.814 .285,71$ & 0,62 & 0,38 & $57.539,68$ & $333.730,16$ \\
\hline 13 & $2.485 .714,29$ & $276.190,48$ & $5.090 .476,19$ & 0,66 & 0,34 & $51.785,71$ & $327.976,19$ \\
\hline 14 & $2.209 .523,81$ & $276.190,48$ & $5.366 .666,67$ & 0,70 & 0,30 & $46.031,75$ & $322.222,22$ \\
\hline 15 & $1.933 .333,33$ & $276.190,48$ & $5.642 .857,14$ & 0,74 & 0,26 & $40.277,78$ & $316.468,25$ \\
\hline 16 & $1.657 .142,86$ & $276.190,48$ & $5.919 .047,62$ & 0,77 & 0,23 & $34.523,81$ & $310.714,29$ \\
\hline 17 & $1.380 .952,38$ & $276.190,48$ & $6.195 .238,10$ & 0,81 & 0,19 & $28.769,84$ & $304.960,32$ \\
\hline 18 & $1.104 .761,90$ & $276.190,48$ & $6.471 .428,57$ & 0,85 & 0,15 & $23.015,87$ & $299.206,35$ \\
\hline 19 & $828.571,43$ & $276.190,48$ & $6.747 .619,05$ & 0,89 & 0,11 & $17.261,90$ & $293.452,38$ \\
\hline 20 & $552.380,95$ & $276.190,48$ & $7.023 .809,52$ & 0,92 & 0,08 & $11.507,94$ & $287.698,41$ \\
\hline 21 & $276.190,48$ & $276.190,48$ & $7.300 .000,00$ & 0,96 & 0,04 & $5.753,97$ & $281.944,44$ \\
\hline \multicolumn{2}{|c|}{ Total payment } & $5.800 .000,00$ & & & & $1.329 .166,67$ & $7.129 .166,67$ \\
\hline
\end{tabular}

From the two illustrations above it is up to Fulan to choose which one he likes. From the experience of experimenting it turns out that customers prefer to choose the first scenario as in Table 1 compared with the second scenario as in 
Table 2, with the reason that the amount of payment that is the same (primary installments + ujrah ) will ease Fulan to prepare money every month in his payment. Although the total payment in the first scenario is slightly more expensive than the second scenario (there is a total payment difference as large as Rp. $85,161.73$ for 21 months or an average amount of Rp. 4,055.32 per month).

What is interesting from table 1 and table 2 is that the ijarah per month that Fulan has to pay always decreases. The reason for this decrease is that when Fulan pays the primary installments, this means Fulan already has the vehicle that he buys as large as the ownership nisbah in column 5. If the total ujrah in table 1 and table 2 is converted in percentage, table 1 is as large as 1.16 percent per month and in table 2 as large as 1.09 percent per month.

To ease the understanding of the payment illustration in table 1 and table 2, next the writer will make some equations for producing numbers in each column. This equation the writer will name IMBT Tami Equation (An equation of the writer's creation). Such as: Th is the buying price of a good in the store (thaman); $\mathrm{K}$ is the payment amount; An is the amount of $\mathrm{n}$ installments; PA is the primary installment; $\mathrm{Sp}$ is the primary payment residual; $\mathrm{Nk}$ is the amount of nisbah ownership of a good; $\mathrm{Uj}$ is the amount of lease of a good (ujrah); $\mathrm{Ue}$ is the estimated economic age of a good; AA is the installment accumulation and; Lk is the contract length in a pact, so mathematically the illustration of Al-Ijarah Muntahiya Bi al Tamlik (Financial Lease With Purchase Option) in table 1 and table 2 is able to be illustrated as the following:

$$
\begin{gathered}
P A=\frac{\mathrm{K}}{\overline{\mathrm{A}}}, \text { is the primary installment (column 3) } \\
\mathrm{AA}=\sum_{k=1}^{n} P \mathrm{~A}, \text { installment accumulation (column 4) } \\
\mathrm{Nk}=\frac{\sum_{k=1}^{n} \mathrm{AA}}{K}, \text { ownership nisbah }(\text { column } 5) \\
\left.U \mathrm{j}=\frac{t h}{\mathrm{Ue}}, \text { is the amount of lease of a good/ ujrah (column } 7\right) \\
\left.\mathrm{An}=\left\{\frac{\mathrm{Th}}{\mathrm{Ue}}(\mathrm{Nk})+\frac{\mathrm{Th}}{\mathrm{Lk}}\right\}, \text { amount of } \mathrm{n} \text { installments (column } 8\right) \\
\mathrm{Sp}=\mathrm{K}-\mathrm{PA}, \text { residual primary payment (column } 2)
\end{gathered}
$$

\subsection{Comparison of Al-Ijarah Muntahiya Bi al Tamlik, Al Murabahah and the Interest System}

Such as explained by the writer in part B above, that for consumptive financing it is better to apply the $I M B T$ pact. For observing the surplus financing model with the IMBT Al-Ijarah Muntahiya Bi al Tamlik (Financial Lease With Purchase Option). For observing the advantage of the IMBT, it needs to be compared with the financing model with the al-Murabahah pact and the financing of leasing with the interest model.

Before the writer presents the counting comparison between IMBT, alMurabahah and the interest system in consumptive financing, firstly there is a need to explain shortly the definitions of both types of the last pacts, which are the alMurabahah pact and the interest system.

1) Al-Murabahah buying and selling

Al-Murabahah is a financing product that is based on the buying and selling pact between the capital provider (finance institution) and the capital user (customer). In practice, al-Murabahah is a buying and selling pact with a primary buying price (selling store price) added with profit (price markup) that the fund 
providing party wants. (Jusoh, 2013:47-55; Djamil, 2012:108-123; Hakim, 2011:225-228).

Generally the equation in counting the bank selling price in the al-Murabahah pact is (Perwataatmadja \& Tanjung, 2011:123):

$$
\mathrm{HJB}=\mathrm{HBB}+\frac{\mathrm{PBU}}{\mathrm{TJP}}+\mathrm{CW}+\mathrm{TK}
$$

Where: HJB is the Bank Selling Price; HBB is the Bank Buying Price; PBU is the Business Cost Portion; TJP is the Financing Amount Target; CW is the Reserve Fund and TK is the Profit Target.

While in the consumptive financing practice in non-bank finance institutions (sharia leasing companies) is (Hakim, 2011:228) formulated as the following:

Selling Price $=$ Store Price + Desired Profit

2) Buying and selling goods with the interest system

Buying and selling with credit based on a pact with the interest system is buying and selling with the primary price (store price) added with the interest amount per month times the length of contract. This is able to be formulated as the following (Dumairy, 2010:35-40):

$$
\mathrm{HJ}=\mathrm{HT}(1+\mathrm{in}) \text { atau } \mathrm{HJ}=\mathrm{HT}(1+\mathrm{i})^{\mathrm{n}}
$$

Where: HJ is the selling price, HT is the store buying price, $\mathrm{i}$ is the interest rate per month, and $\mathrm{n}$ is the length of contract.

For observing a comparison of the three types of financing pacts, in table 3 a financing model with the al-Murabahah pact is presented and in table 4 the leasing financing with an interest system is presented. For the IMBT type pact, it is already illustrated before (observe table 1 and table 2 above).

If the margin total and the interest total in the mentioned table 3 and table 4 is converted in percentage, in table 3 it is as large as 1.23 percent per month and in table 4 as large as 1.20 percent per month. From the financing illustration with the $I M B T$ pact, the al-Murabahah pact and the interest system it is seen that financing with the interest system has the smallest margin rate per month, which is as large as 1.20 percent per month. Financing with the al-Murabahah pact is as large as 1.23 percent. Meanwhile the IMBT pact financing with per month primary installments paid the same is as large as 1.09 percent per month. This means that financing with the IMBT pact is more advantageous than the al-Murabahah pact and the interest system. Other than that, if in a certain month the buyer does not have money to pay the primary installment in the IMBT pact, the buyer is able to just pay the lease (ujrah).

Therefore there is a remission (does not burden) for the buyer party. It is different if the credit buying and selling is determined based on a certain interest rate, the debtor has the burden of primary debt added with interest, when the debtor postpones the payment because of any reason.

Table 3 Payment Installments of a Two Wheeled Motor Vehicle With the al-Murabahah Pact

\begin{tabular}{cccccccc}
\hline Month & $\begin{array}{c}\text { Primary } \\
\text { Residual }\end{array}$ & \multicolumn{2}{c}{$\begin{array}{c}\text { Primary } \\
\text { Installment }\end{array}$} & Margin & \multicolumn{2}{c}{$\begin{array}{c}\text { Total } \\
\text { Installment }\end{array}$} \\
\hline 1 & $\mathrm{Rp} 16.161 .200$ & $\mathrm{Rp}$ & 302.824 & $\mathrm{Rp}$ & 345.176 & $\mathrm{Rp}$ & 648.000 \\
\hline 2 & $\mathrm{Rp} \mathrm{15.858.376}$ & $\mathrm{Rp}$ & 309.292 & $\mathrm{Rp}$ & 338.708 & $\mathrm{Rp}$ & 648.000 \\
\hline 3 & $\mathrm{Rp} \mathrm{15.549.084}$ & $\mathrm{Rp}$ & 315.898 & $\mathrm{Rp}$ & 332.102 & $\mathrm{Rp}$ & 648.000 \\
\hline 4 & $\mathrm{Rp} \mathrm{15.233.186}$ & $\mathrm{Rp}$ & 322.645 & $\mathrm{Rp}$ & 325.355 & $\mathrm{Rp}$ & 648.000 \\
\hline
\end{tabular}


The Application of Al-Ijarah Muntahiya Bi al tamlik (Financial Lease With Purchase Option) As a Financing Solution in the Sharia Non-Bank Finance Industry

\begin{tabular}{|c|c|c|c|c|c|c|c|}
\hline \multirow{2}{*}{$\begin{array}{c}\text { Month } \\
5\end{array}$} & \multirow{2}{*}{$\begin{array}{c}\begin{array}{c}\text { Primary } \\
\text { Residual }\end{array} \\
\text { Rp } 14.910 .542 \\
\end{array}$} & \multicolumn{2}{|c|}{$\begin{array}{c}\text { Primary } \\
\text { Installment }\end{array}$} & \multicolumn{2}{|c|}{ Margin } & \multicolumn{2}{|c|}{$\begin{array}{c}\text { Total } \\
\text { Installment }\end{array}$} \\
\hline & & $\mathrm{Rp}$ & 329.536 & $\mathrm{Rp}$ & 318.464 & $\mathrm{Rp}$ & 648.000 \\
\hline 6 & Rp 14.581.006 & $\mathrm{Rp}$ & 336.574 & $\mathrm{Rp}$ & 311.426 & $\mathrm{Rp}$ & 648.000 \\
\hline 7 & Rp 14.244.431 & $\mathrm{Rp}$ & 343.763 & $\mathrm{Rp}$ & 304.237 & $\mathrm{Rp}$ & 648.000 \\
\hline 8 & Rp 13.900.668 & $\mathrm{Rp}$ & 351.105 & $\mathrm{Rp}$ & 296.895 & $\mathrm{Rp}$ & 648.000 \\
\hline 9 & Rp 13.549.563 & $\mathrm{Rp}$ & 358.604 & $\mathrm{Rp}$ & 289.396 & $\mathrm{Rp}$ & 648.000 \\
\hline 10 & Rp 13.190.959 & $\mathrm{Rp}$ & 366.263 & $\mathrm{Rp}$ & 281.737 & $\mathrm{Rp}$ & 648.000 \\
\hline 11 & Rp 12.824.696 & $\mathrm{Rp}$ & 374.086 & $\mathrm{Rp}$ & 273.914 & $\mathrm{Rp}$ & 648.000 \\
\hline 12 & Rp 12.450 .610 & $\mathrm{Rp}$ & 382.076 & $\mathrm{Rp}$ & 265.924 & $\mathrm{Rp}$ & 648.000 \\
\hline 13 & Rp 12.068.534 & $\mathrm{Rp}$ & 390.236 & $\mathrm{Rp}$ & 257.764 & $\mathrm{Rp}$ & 648.000 \\
\hline 14 & Rp 11.678.297 & $\mathrm{Rp}$ & 398.571 & $\mathrm{Rp}$ & 249.429 & $\mathrm{Rp}$ & 648.000 \\
\hline 15 & Rp 11.279.726 & $\mathrm{Rp}$ & 407.084 & $\mathrm{Rp}$ & 240.916 & $\mathrm{Rp}$ & 648.000 \\
\hline 16 & Rp 10.872.642 & $\mathrm{Rp}$ & 415.779 & $\mathrm{Rp}$ & 232.221 & $\mathrm{Rp}$ & 648.000 \\
\hline 17 & Rp 10.456.863 & $\mathrm{Rp}$ & 424.659 & $\mathrm{Rp}$ & 223.341 & $\mathrm{Rp}$ & 648.000 \\
\hline 18 & $\mathrm{Rp} 10.032 .204$ & $\mathrm{Rp}$ & 433.729 & $\mathrm{Rp}$ & 214.271 & $\mathrm{Rp}$ & 648.000 \\
\hline 19 & R p 9.598.475 & $\mathrm{Rp}$ & 442.993 & $\mathrm{Rp}$ & 205.007 & $\mathrm{Rp}$ & 648.000 \\
\hline 20 & Rp 9.155 .482 & $\mathrm{Rp}$ & 452.454 & $\mathrm{Rp}$ & 195.546 & $\mathrm{Rp}$ & 648.000 \\
\hline 21 & $\mathrm{Rp} \quad 8.703 .028$ & $\mathrm{Rp}$ & 462.118 & $\mathrm{Rp}$ & 185.882 & $\mathrm{Rp}$ & 648.000 \\
\hline 22 & $\mathrm{Rp} \quad 8.240 .910$ & $\mathrm{Rp}$ & 471.988 & $\mathrm{Rp}$ & 176.012 & $\mathrm{Rp}$ & 648.000 \\
\hline 23 & $\mathrm{Rp} 7.768 .922$ & $\mathrm{Rp}$ & 482.069 & $\mathrm{Rp}$ & 165.931 & $\mathrm{Rp}$ & 648.000 \\
\hline 24 & $\mathrm{Rp} \quad 7.286 .853$ & $\mathrm{Rp}$ & 492.365 & $\mathrm{Rp}$ & 155.635 & $\mathrm{Rp}$ & 648.000 \\
\hline 25 & Rp $\quad 6.794 .488$ & $\mathrm{Rp}$ & 502.881 & $\mathrm{Rp}$ & 145.119 & $\mathrm{Rp}$ & 648.000 \\
\hline 26 & Rp $\quad 6.291 .607$ & $\mathrm{Rp}$ & 513.622 & $\mathrm{Rp}$ & 134.378 & $\mathrm{Rp}$ & 648.000 \\
\hline 27 & Rp $\quad 5.777 .985$ & $\mathrm{Rp}$ & 524.592 & $\mathrm{Rp}$ & 123.408 & $\mathrm{Rp}$ & 648.000 \\
\hline 28 & $\begin{array}{ll}\mathrm{Rp} & 5.253 .393 \\
\end{array}$ & $\mathrm{Rp}$ & 535.796 & $\mathrm{Rp}$ & 112.204 & $\mathrm{Rp}$ & 648.000 \\
\hline 29 & $\mathrm{Rp} \quad 4.717 .597$ & $\mathrm{Rp}$ & 547.240 & $\mathrm{Rp}$ & 100.760 & $\mathrm{Rp}$ & 648.000 \\
\hline 30 & $\mathrm{Rp} \quad 4.170 .357$ & $\mathrm{Rp}$ & 558.928 & $\mathrm{Rp}$ & 89.072 & $\mathrm{Rp}$ & 648.000 \\
\hline 31 & $\mathrm{Rp} \quad 3.611 .428$ & $\mathrm{Rp}$ & 570.866 & $\mathrm{Rp}$ & 77.134 & $\mathrm{Rp}$ & 648.000 \\
\hline 32 & $\mathrm{Rp} \quad 3.040 .562$ & $\mathrm{Rp}$ & 583.059 & $\mathrm{Rp}$ & 64.941 & $\mathrm{Rp}$ & 648.000 \\
\hline 33 & Rp $\quad 2.457 .504$ & $\mathrm{Rp}$ & 595.512 & $\mathrm{Rp}$ & 52.488 & $\mathrm{Rp}$ & 648.000 \\
\hline 34 & $\mathrm{Rp} \quad 1.861 .992$ & $\mathrm{Rp}$ & 608.231 & $\mathrm{Rp}$ & 39.769 & $\mathrm{Rp}$ & 648.000 \\
\hline 35 & $\begin{array}{ll}\mathrm{Rp} & 1.253 .761 \\
\end{array}$ & $\mathrm{Rp}$ & 621.222 & $\mathrm{Rp}$ & 26.778 & $\mathrm{Rp}$ & 648.000 \\
\hline \multirow[t]{2}{*}{36} & $\mathrm{Rp} \quad 632.542$ & $\mathrm{Rp}$ & 634.490 & $\mathrm{Rp}$ & 13.510 & $\mathrm{Rp}$ & 648.000 \\
\hline & Total Payment & \multicolumn{2}{|c|}{ Rp 16.163.151 } & \multicolumn{2}{|c|}{$\mathrm{Rp} 7.164 .849$} & \multicolumn{2}{|c|}{$\operatorname{Rp} 23.328 .000$} \\
\hline
\end{tabular}

Source: PT. Federal International Finance Pontianak Branch

Table 4 Interest System Payment Installments of a Two Wheeled Motor Vehicle

\begin{tabular}{cccccccc}
\hline Month & $\begin{array}{c}\text { Primary } \\
\text { Residual }\end{array}$ & \multicolumn{2}{c}{$\begin{array}{c}\text { Primary } \\
\text { Installment }\end{array}$} & Margin & \multicolumn{2}{c}{$\begin{array}{c}\text { Total } \\
\text { Installment }\end{array}$} \\
\hline 1 & $\mathrm{Rp} 12.138 .541$ & $\mathrm{Rp}$ & 239.013 & $\mathrm{Rp}$ & 252.987 & $\mathrm{Rp}$ & 492.000 \\
\hline 2 & $\mathrm{Rp} 11.899 .528$ & $\mathrm{Rp}$ & 243.994 & $\mathrm{Rp}$ & 248.006 & $\mathrm{Rp}$ & 492.000 \\
\hline 3 & $\mathrm{Rp} 11.655 .534$ & $\mathrm{Rp}$ & 249.079 & $\mathrm{Rp}$ & 242.921 & $\mathrm{Rp}$ & 492.000 \\
\hline 4 & $\mathrm{Rp} 11.406 .455$ & $\mathrm{Rp}$ & 254.270 & $\mathrm{Rp}$ & 237.730 & $\mathrm{Rp}$ & 492.000 \\
\hline 5 & $\mathrm{Rp} 11.152 .185$ & $\mathrm{Rp}$ & 259.570 & $\mathrm{Rp}$ & 232.430 & $\mathrm{Rp}$ & 492.000 \\
\hline
\end{tabular}




\begin{tabular}{|c|c|c|c|c|c|c|c|}
\hline \multirow{2}{*}{$\begin{array}{c}\text { Month } \\
6\end{array}$} & \multirow{2}{*}{$\begin{array}{c}\begin{array}{c}\text { Primary } \\
\text { Residual }\end{array} \\
\text { Rp 10.892.615 } \\
\end{array}$} & \multicolumn{2}{|c|}{$\begin{array}{c}\text { Primary } \\
\text { Installment }\end{array}$} & \multicolumn{2}{|c|}{ Margin } & \multicolumn{2}{|c|}{$\begin{array}{c}\text { Total } \\
\text { Installment } \\
\end{array}$} \\
\hline & & $\mathrm{Rp}$ & 264.980 & $\mathrm{Rp}$ & 227.020 & $\mathrm{Rp}$ & 492.000 \\
\hline 7 & Rp 10.627.635 & $\mathrm{Rp}$ & 270.502 & $\mathrm{Rp}$ & 221.498 & $\mathrm{Rp}$ & 492.000 \\
\hline 8 & $\operatorname{Rp} 10.357 .133$ & $\mathrm{Rp}$ & 276.140 & $\mathrm{Rp}$ & 215.860 & $\mathrm{Rp}$ & 492.000 \\
\hline 9 & Rp 10.080.993 & $\mathrm{Rp}$ & 281.895 & $\mathrm{Rp}$ & 210.105 & $\mathrm{Rp}$ & 492.000 \\
\hline 10 & Rp 9.799 .098 & $\mathrm{Rp}$ & 287.770 & $\mathrm{Rp}$ & 204.230 & $\mathrm{Rp}$ & 492.000 \\
\hline 11 & $\mathrm{Rp} \quad 9.511 .328$ & $\mathrm{Rp}$ & 293.768 & $\mathrm{Rp}$ & 198.232 & $\mathrm{Rp}$ & 492.000 \\
\hline 12 & Rp 9.217 .560 & $\mathrm{Rp}$ & 299.891 & $\mathrm{Rp}$ & 192.109 & $\mathrm{Rp}$ & 492.000 \\
\hline 13 & Rp $\quad 8.917 .669$ & $\mathrm{Rp}$ & 306.141 & $\mathrm{Rp}$ & 185.859 & $\mathrm{Rp}$ & 492.000 \\
\hline 14 & $\mathrm{Rp} \quad 8.611 .528$ & $\mathrm{Rp}$ & 312.521 & $\mathrm{Rp}$ & 179.479 & $\mathrm{Rp}$ & 492.000 \\
\hline 15 & Rp 8.299 .007 & $\mathrm{Rp}$ & 319.035 & $\mathrm{Rp}$ & 172.965 & $\mathrm{Rp}$ & 492.000 \\
\hline 16 & Rp 7.979 .972 & $\mathrm{Rp}$ & 325.684 & $\mathrm{Rp}$ & 166.316 & $\mathrm{Rp}$ & 492.000 \\
\hline 17 & Rp 7.654 .288 & $\mathrm{Rp}$ & 332.472 & $\mathrm{Rp}$ & 159.528 & $\mathrm{Rp}$ & 492.000 \\
\hline 18 & $\mathrm{Rp} \quad 7.321 .816$ & $\mathrm{Rp}$ & 339.401 & $\mathrm{Rp}$ & 152.599 & $\mathrm{Rp}$ & 492.000 \\
\hline 19 & Rp $\quad 6.982 .415$ & $\mathrm{Rp}$ & 346.475 & $\mathrm{Rp}$ & 145.525 & $\mathrm{Rp}$ & 492.000 \\
\hline 20 & $\begin{array}{ll}\mathrm{Rp} & 6.635 .940 \\
\end{array}$ & $\mathrm{Rp}$ & 353.696 & $\mathrm{Rp}$ & 138.304 & $\mathrm{Rp}$ & 492.000 \\
\hline 21 & Rp $\quad 6.282 .244$ & $\mathrm{Rp}$ & 361.068 & $\mathrm{Rp}$ & 130.932 & $\mathrm{Rp}$ & 492.000 \\
\hline 22 & Rp 5.921 .176 & $\mathrm{Rp}$ & 368.593 & $\mathrm{Rp}$ & 123.407 & $\mathrm{Rp}$ & 492.000 \\
\hline 23 & Rp 5.552 .583 & $\mathrm{Rp}$ & 376.275 & $\mathrm{Rp}$ & 115.725 & $\mathrm{Rp}$ & 492.000 \\
\hline 24 & $\begin{array}{ll}\mathrm{Rp} & 5.176 .308 \\
\end{array}$ & $\mathrm{Rp}$ & 384.117 & $\mathrm{Rp}$ & 107.883 & $\mathrm{Rp}$ & 492.000 \\
\hline 25 & $\mathrm{Rp} \quad 4.792 .191$ & $\mathrm{Rp}$ & 392.123 & $\mathrm{Rp}$ & 99.877 & $\mathrm{Rp}$ & 492.000 \\
\hline 26 & $\mathrm{Rp} \quad 4.400 .068$ & $\mathrm{Rp}$ & 400.295 & $\mathrm{Rp}$ & 91.705 & $\mathrm{Rp}$ & 492.000 \\
\hline 27 & Rp 3.999 .773 & $\mathrm{Rp}$ & 408.638 & $\mathrm{Rp}$ & 83.362 & $\mathrm{Rp}$ & 492.000 \\
\hline 28 & $\mathrm{Rp} \quad 3.591 .135$ & $\mathrm{Rp}$ & 417.155 & $\mathrm{Rp}$ & 74.845 & $\mathrm{Rp}$ & 492.000 \\
\hline 29 & $\mathrm{Rp} \quad 3.173 .980$ & $\mathrm{Rp}$ & 425.849 & $\mathrm{Rp}$ & 66.151 & $\mathrm{Rp}$ & 492.000 \\
\hline 30 & $\mathrm{Rp} \quad 2.748 .131$ & $\mathrm{Rp}$ & 434.724 & $\mathrm{Rp}$ & 57.276 & $\mathrm{Rp}$ & 492.000 \\
\hline 31 & Rp 2.313 .407 & $\mathrm{Rp}$ & 443.785 & $\mathrm{Rp}$ & 48.215 & $\mathrm{Rp}$ & 492.000 \\
\hline 32 & $\mathrm{Rp} \quad 1.869 .622$ & $\mathrm{Rp}$ & 453.034 & $\mathrm{Rp}$ & 38.966 & $\mathrm{Rp}$ & 492.000 \\
\hline 33 & $\mathrm{Rp} \quad 1.416 .588$ & $\mathrm{Rp}$ & 462.476 & $\mathrm{Rp}$ & 29.524 & $\mathrm{Rp}$ & 492.000 \\
\hline 34 & $\mathrm{Rp} \quad 954.112$ & $\mathrm{Rp}$ & 472.115 & $\mathrm{Rp}$ & 19.885 & $\mathrm{Rp}$ & 492.000 \\
\hline 35 & $\mathrm{Rp} \quad 481.997$ & $\mathrm{Rp}$ & 481.997 & $\mathrm{Rp}$ & 10.003 & $\mathrm{Rp}$ & 492.000 \\
\hline \multicolumn{2}{|c|}{ Total Pembayaran } & $\mathrm{Rp} 1$ & .138 .541 & $\mathrm{Rp}$ & 5.081 .459 & $\mathrm{Rp}$ & 17.220 .000 \\
\hline
\end{tabular}

Source: PT. Federal International Finance Pontianak Branch

The application of the $I M B T$ pact is not only applied to the consumptive customers, but it is also able to be applied for financing of productive business asset ownership, such as for the procurement of transportation fleets such as taxis, motorcycle taxis and other types of transport.

Just as an illustration, in the following the writer submits the interview results of the writer with several Express Taxi Drivers and LPG auto rickshaw drivers that operate in the Jakarta area. For the Express Taxi Drivers (white color), every day they have to fulfill a deposit as large as Rp. 300,000, in details as many as Rp. 270,000 for the company and Rp. 30,000 for reserves of the vehicle maintenance fund (this fund is also deposited to the company). After the taxi operates for 6 years, the mentioned ex taxi becomes owned by the driver. After reaching the age of 6 , 
the taxi car has to be rehabilitated with a new car, so the Driver only has a car that is not able to be functioned as a taxi again.

From the obtained income, the drivers sometimes only bring home money as many as Rp. 50,000 per day. If compared with the income that the company receives, which is Rp. 270,000 x 365 days x $6=$ Rp. 591,300,000 - Rp. 50,000,000 (vehicle down payment) the average is as many as Rp. 540,000,000 per vehicle as long as 6 years or the average is as many as Rp. 90,166,667 per year per vehicle. While the Driver, because of the deposit amount and fuel usage, say that the average net income is Rp. 75,000 x $365=$ Rp. 27,375,000 per year or an average of Rp. 2,281,250 per month. It is able to be summarized that the income that the company receives is as many as 3.3 times of the driver's income.

While LPG auto rickshaws (blue color), every day the driver has to fulfill the deposit of about Rp. 135,000 - Rp.175,000 per day (depending on company policy). It is different with Express Taxi Drivers, the LPG auto rickshaw drivers do not have a chance to own the auto rickshaw that they use, no matter how long they operate it, the auto rickshaw is still owned by the company. The net income that they receive every day is not much different with the income of Express Taxi Drivers.

The two case examples above show the inequality of income that workers receive. Workers that are the backbone of the company for their operations, only get a small part compared with the owner. It is common if we see that this reality causes a very large gap between the capital owners and the workers. Even though according to Ibn Khaldun, the workers have a strategic position in production operations and the lifeline of a business.

This condition of the people will not experience meaningful change, when there is no effort from the related party for improving it. In the Quran verse piece of Al-Isra [17] Allah says, which means: "If you do good deeds (means) you do good deeds for yourself and if you do bad deeds, The (evil) is for yourself",

In the case of the taxi driver and auto rickshaw driver such as explained above, If the $I M B T$ financing model is applied, the taxi driver and the auto rickshaw driver are able to have their own business and vehicle, without having to depend on the company they work in. In here, the role of sharia banking/finance institution becomes important, not only as a distributor of loan funds (business credit) to businesspeople with the motive to obtain profit for themselves, but they have to raise business motivation for the lower class people (grass root) so they are able to rise from being backwards and poor, towards the reach of an economic growth with equity, according to the principles of Islamic economy.

\section{SUMMARY}

This writing proves, that the application of the IMBT (Al-Ijarah Muntahiya Bi al Tamlik) pact is more profitable than the al-Murabahah pact and the interest system. Other than that, it reflects the presence of the justice principle and togetherness between the capital owner party (shahib al mal) with those that need financing.

In building the economy, welfare has to be prioritized equally and evenly for the people, not just chasing a high economic growth rate. The lower class people (grassroots) have to be given serious attention so they are able to be the backbone of the economy. The trickle-down effect paradigm is not relevant anymore, because 
it is proven to not form, and because of that it has to be changed with a new paradigm through the inter linkage (interdependence) principle and the bottom up effect for spurring growth and developing awareness and motivation from the lower class people in increasing their economy for catching up, through a justice economy where moral and ethical values have to be the pillar in the economy.

\section{References}

Abdullah, N. I., \& Dusuki, A. W. (tt). A Critical Appraisal of Al-Ijarah Thumma al-Bay' (AITAB): operation:' Issues and Prospects. 4th International Islamic Banking and Finance Conference, 10-11. Malaysia: Monash University of Malaysia. Accessed on April 22, 2015.

Al-Mishry, R. Y. (1998/1418 H). Bai’ al-Taqsith Tahlîl fiqhy wa iqtishâdy. Jedah: Jami’ah Al-Malik 'Abdul Aziz.

Ar-Rahim, M. A.-R. (1410 H/ 1990 M). Tuhfatu al-Ahwazi bi Syarhi Jami' atTirmizi, Juz IV (Vol. Print I). Beirut: Dar al-Kutub al-Islami.

Bustami. (2015). Pemberdayaan Usaha Mikro, Kecil Dan Menengah di Kalimantan Barat (Perspektif Ekonomi Islam). Jakarta: Graduate School of Syarif Hidayatullah Islamic Public University.

Djamil, F. (2012). Penerapan Hukum Perjanjian dalam Transaksi di Lembaga Keuangan syariah . Jakarta: Sinar Grafika.

Dumairy. (2010). Matematika Terapan untuk Bisnis \& Ekonomi. Yogyakarta: BPFE.

Hakim, A. A. (2011). Fiqih Perbankan Syariah: Transformasi Fiqih Muamalah ke dalam Peraturan Perundang-undangan. Bandung: PT. Refika Aditama.

Ibn Khaldun, A. (2001 M/ 1421 H). Muqaddimah ibn Khaldun. Beirut: Daar al Fikr.

Jusoh, M. D. (2013). Al-Murabaha:' Implications on Financial Stability and Islamic Finance Model. islamiyyat, 35 No. 2, 47 - 55.

Kasmir. (2000). Bank dan Lembaga Keuangan Lainnya (Vol. Print IV). Jakarta: PT. Rajagrafindo Persada.

Perwataatmadja, K. A., \& Tanjung, H. (2011). Bank Syariah: Teori, Praktik, dan Peranannya. Jakarta: Celestial Publishing.

Zuhaily, Wahbah. (2002). Al-Mu'âmalat Al-Mâliyah Al-Ma'âshirah. Damaskus: Darul Fikr. 